\title{
Distribution of Ostracoda in Lake Sediments around Sanduru-Hospet with Special reference to pollution
}

\author{
Lavanya Hegde ${ }^{1}$, A.S.Vaidya ${ }^{2}$, B.K.Wodeyar ${ }^{3}$, Alok Hegde ${ }^{4}$ \\ 1. Dept of Geology, Government Engineering College,Karwar \\ 2. UGC-Human Resource Development Centre, Bangalore University, \\ 3. Dept. Of Geology, Karnatak University, Dharwad \\ 4.Dept of Earth science, Manasagangotri, University of Mysore, Mysuru
}

\begin{abstract}
The objective of this paper is to show the utility of ostracoda in monitoring the impact of growing industrilal and mining pollution in the lakes situated around Sandur Schist belt Bellary district, Karnataka( Hospet North Eastern region of Karnataka). Bio mapping is a popular technique to monitor pollution level of water bodies which are used for drinking and agricultural purposes. Soil and water samples were collected from four lakes for ostracoda content from the study area. Eighteen ostracode taxa have been identified and recorded. It is interesting to note that the water and bottom sediment samples of lakes analysed, indicate high Fe and Mn content which is due to erosion and flooding during monsoon and transported down streams to lakes from near by mining areas The factors that influence the distribution of ostracode assemblages in the lakes and impact of pollution are discussed briefly along with ecology in the present paper.
\end{abstract}

Key Words: Mining pollution, Sandur Schist belt, Bio-indicators, Recent Ostracoda.

\section{INTRODUCTION}

Ostracodes are bivalve micro crustaceans inhabit all aquatic bodies including the terrestrial environment. These micro crustaceans are very sensitive and respond very quickly to any environmental changes due to either by anthropogenic or natural cause. These micro-crustaceans show high sensitivity to pollution especially use of pesticides and heavy metal concetrations. Thus they can be used as a tool in identifying the stressed environments viz. Global warming, oxygen deficiency, oil and gas seepages, mining and different types of anthropogenic pollution.

In the recent years one of the modern techniques viz. Bio mapping is employed on rivers and aquatic bodies in order to monitor the pollution level which are utilized for either domestic or agriculture work etc. Federal Republic of Germany initiated this technology for the first time. The tools needed for this purpose are biotic assemblages along with physico-chemical and other parameters of the water bodies. The concept of this experiment not only helps in determining the ecological environmental effects but also useful in protecting endangered biotic fauna/species and surface waters from increasing pollution by urban anthropogenic and other activities. The ratios of still to cosmopolitan species also throw light on their functional, adoptability and structural efficiencies

Hence with these ideas micro crustaceans which are well preserved with taxonomic development, have been considered as the proxies for environmental evaluation of some of lake sediments around Hospet is the objective of this paper. Further, to identify indicator species to infer the current status of water bodies which are affected due to mining dumps and anthropogenic activities. Besides to know whether there are any tolerant forms available under such prevailing conditions..
A survey of literature reveals that very little work has been made pertaining to pollution aspects in India using microcrustacians as a tool. The important studies available so far to our knowledge are those of Puri (1966), Delorme (1969), Bhatia and Singh (1971), Mannikeri and Vaidya (1987), Vaidya (1987, 1996) and Mathur et.al (2001), who have discussed about ecology and paleoecology and distribution of ostracodes. However in recent years Kulkoyluoglu (2005),Faruk and Okan (2006), Padmanabha and Belagali (2008),,Koorosh et al.(2008), Liping Zhu et.al (2010),Mohammad Shumaimi et.al (2011), Narasimha Ramulu et.al (2011), Mischke et.al (2012), Ruiz et al (2013), and Hussain (2017) are others who have carried out research work on pollution, impact of toxicity of metal and other environmental aspects.

The study area refers to silted ponds and large tanks (lakes) in northern part of Sandur Schist Belt (SSB) (map1). This area is known for its rich iron and manganese ore deposits and large scale of mining is witnessed since 1980. The mining and related activities have been producing large quantities of waste and ore fines which are dumped in the mine vicinity. Mining activities are concentrated mostly on the ridges of the hill ranges around SSB belt. During rainy season the fines of ores and its dust are carried by runoff and finally get deposited in the large, ponds and north eastern part of Tungabhadra reservoir resulting in diminishing of water quantity. This has caused ecological imbalance such as minor change of flow direction of rivulets, high rate of weathering of hill slopes, pollution of surface water and change in the fauna and flora distribution and diversity.

Since the iron ore mining is concentrated in the eastern side of the schist belt, which is comprised of BIFs and metavolcanics, the ponds and large tanks which are fed by 
eastern side range drainage system are polluted due to mining activity, (map.1,Fig.1,2,3and 4). Whereas the ponds and the tanks located on the western margin of the schist belt are fed by western drainage which carries little sediment and ore fines load. This part of the region is comprised of gneissic complex. As a result, these surface water bodies are not polluted by mine waste.
The location of the water bodies from where the sampling was done adapting standard procedure, is shown in the location map 1. The water analysis and the type of substratum/bottom sediment of different water bodies is shown in table.2. The Checklist of ostracodes and their taxa wise frequency distribution in various ponds and lakes are given in the table. 3

Map1: Location map of the study area

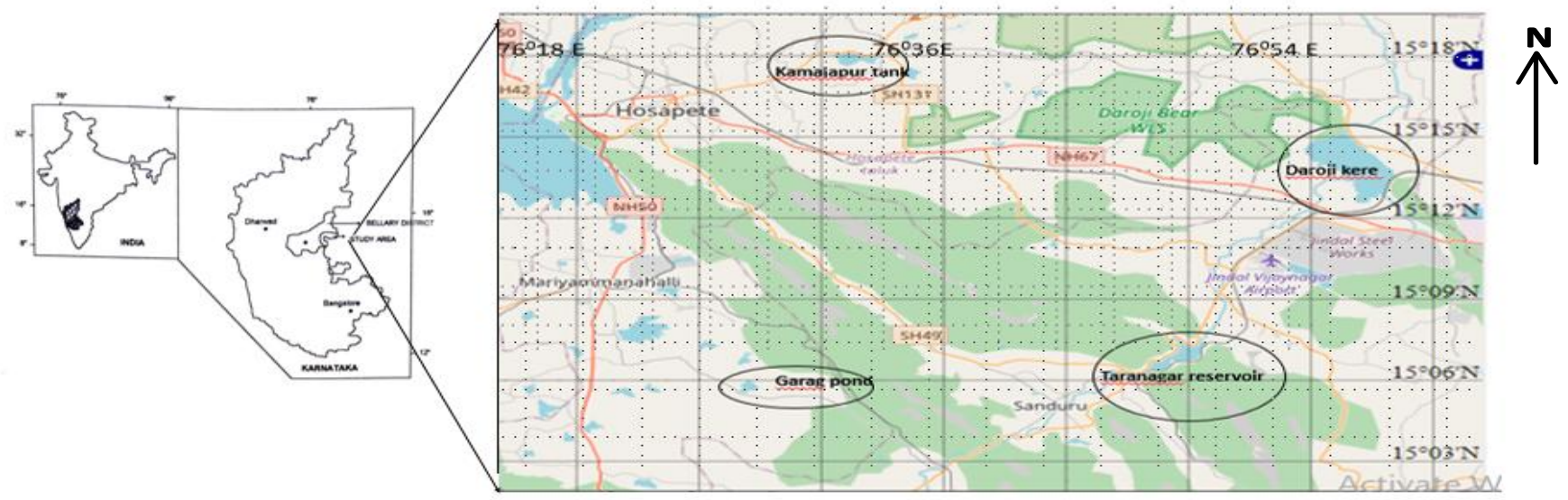

\begin{tabular}{|c|c|c|c|c|c|c|c|c|c|c|c|c|c|c|c|c|}
\hline & $\mathrm{pH}$ & EC & $\mathrm{Ca}$ & $\mathrm{Mg}$ & $\mathrm{Na}$ & $\mathbf{K}$ & $\mathrm{CO}_{3}$ & $\mathrm{HCO}_{3}$ & $\mathrm{SO}_{4}$ & $\mathrm{Cl}$ & TH & TDS & $\mathrm{Fe}$ & Mn & Zn & $\mathrm{Cu}$ \\
\hline $\begin{array}{l}\text { Kamalapur } \\
\text { Tank }\end{array}$ & 8.05 & 200 & 42.08 & 10.96 & 33.51 & 5.03 & 250 & 100 & 37 & 113 & 150 & 129 & 8.2 & 1.43 & 0.06 & 0.11 \\
\hline Daroji Tank & 8.1 & 800 & 50.1 & 1.19 & 174.53 & 8.76 & 200 & 175 & 0 & 461.5 & 130 & 516 & 11 & 0.43 & 0.51 & 0.54 \\
\hline Garag Pond & 8.18 & 0 & 20.04 & 0.24 & 10.5 & 3.57 & 0 & 500 & 309.6 & 142 & 350 & 70.2 & 8.5 & 0.01 & 0.02 & 0.41 \\
\hline $\begin{array}{l}\text { Taranagar } \\
\text { Reservoir }\end{array}$ & 8.5 & 400 & 40.08 & 2.45 & 13.94 & 4.1 & 150 & 150 & 38.4 & 198.8 & 90 & 258 & 0.6 & 0 & 0.03 & 0.33 \\
\hline & Exc & $\overline{\mathrm{HH}}$ & nar: & ters a & xpresse & & $\mathrm{EC}$ & seij & $\mathrm{s} / \mathrm{cm}$ & & & & & & & \\
\hline
\end{tabular}

\begin{tabular}{|l|l|l|l|l|l|l|l|l|}
\hline Table 2: Partial Chemical Analysis of sediment samples \\
\hline & $\mathrm{SiO2}$ & $\mathrm{Mg}$ & $\mathrm{Na}$ & $\mathrm{K}$ & $\mathrm{Fe}$ & $\mathrm{Mn}$ & $\mathrm{Zn}$ & $\mathrm{Cu}$ \\
\hline Kamalapur Tank & 67.80 & 1.00 & 0.80 & 1.69 & 29.00 & 08 & 1.00 & 3.95 \\
\hline Daroji Tank & 59.0 & 2.45 & 0.5 & 0.29 & 25.07 & 11 & 2.00 & 2.83 \\
\hline Garag Pond & 80.6 & 2.0 & 3.55 & 1.62 & 16.30 & 18 & 1.09 & 3.00 \\
\hline Taranagar Reservoir & 69.40 & 1.85 & 2.20 & 1.60 & 25.00 & 13 & 6.19 & 2.00 \\
\hline
\end{tabular}

All elements expressed in ppm

Table 3. Check List of Ostracoda and their frequency wise distribution in water bodies of study area.

\begin{tabular}{|c|c|c|c|c|}
\hline Ostracoda taxa & Kamalapur tank & $\begin{array}{c}\text { Daroji } \\
\text { tank }\end{array}$ & $\begin{array}{c}\text { Garag } \\
\text { pond }\end{array}$ & Taranagar reserviour \\
\hline $\begin{array}{c}\text { Stenocypris major } \\
\text { Strandasia indica } \\
\text { (Hartmann) }\end{array}$ & $\mathrm{C}$ & - & - & - \\
\hline S.hislopi & $\mathrm{C}$ & - & - & - \\
\hline S. hartmanni & $\mathrm{C}$ & - & - & - \\
\hline Potamocypris $s p$ & - & $\mathrm{R}$ & - & - \\
\hline
\end{tabular}




\begin{tabular}{|c|c|c|c|c|}
\hline Parastenocypris sp & $\mathrm{C}$ & & - & - \\
\hline llyocypris gibba & $\mathrm{C}$ & $\mathrm{C}$ & - & - \\
\hline I.sp & $\mathrm{R}$ & - & - & - \\
\hline I. bradyi Sars & $\mathrm{C}$ & $\mathrm{C}$ & - & - \\
\hline $\begin{array}{c}\text { Hemicypris fossulata } \\
\text { (Varva) }\end{array}$ & $\mathrm{C}$ & $\mathrm{R}$ & - & - \\
\hline H.sp & $\mathrm{R}$ & - & - & - \\
\hline H. pandei & $\mathrm{C}$ & $\mathrm{R}$ & - & - \\
\hline $\begin{array}{c}\text { H. battishi } \\
\text { (Mannikeri) }\end{array}$ & $\mathrm{C}$ & $\mathrm{R}$ & - & - \\
\hline $\begin{array}{c}\text { Eucypris. sp } \\
\text { Cypris subglobosa } \\
\text { (Sowerby) }\end{array}$ & $\mathrm{R}$ & - & - & - \\
\hline $\begin{array}{c}\text { Cyprinotus salinus } \\
\text { (Brady) }\end{array}$ & $\mathrm{A}$ & $\mathrm{C}$ & - & - \\
\hline $\begin{array}{c}\text { Candona sp } \\
\text { Candonopsis kingsleli } \\
\text { (Brady and Robertson) }\end{array}$ & $\mathrm{R}$ & - & - & - \\
\hline
\end{tabular}

\section{OBSERVATIONS AND DISCUSSION}

The ecology and distribution of ostracodes from 4 aquatic bodies viz., Kamalapur tank, Daroji Kere, Taranagar Reservoir, Garag pond(Fig1,Fig2,Fig3 and Fig 4) around Hospet are discussed.
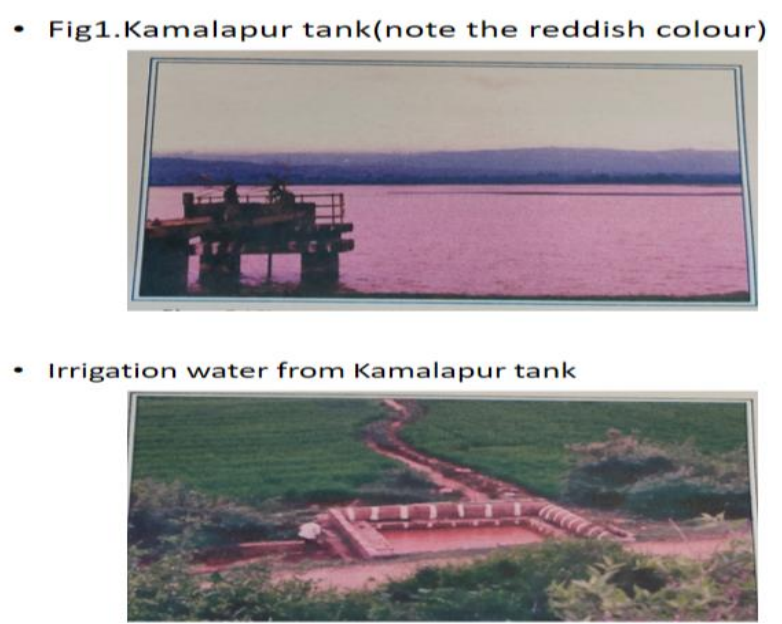

Of the four inland water bodies two ponds/lakes (Kamalapur and Daroji) have yielded good number of species. The substrate of theses samples of lakes being mixture of sand and mud with moderate vegetative matter which includes water weeds and paddy and sugarcane fields in the adjacent areas. As mentioned earlier the water of surface water bodies located on the eastern side of SSB is characterized by moderate TDS and high suspended matter and sediments of silt grade with rich vegetation along the borders. Besides, the
About 20 samples were collected randomly from these water bodies at a depth of one meter and water analysis and type of bottom sediment of aquatic bodies/lakes was also carried out. The study of these lakes shows simple association of different ostracoda which are known and common to freshwater ecosystem.

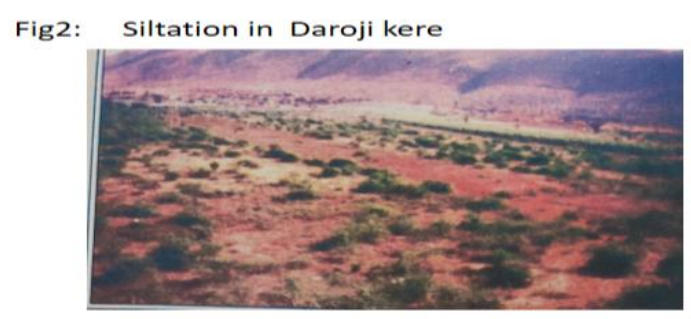

Fig4: Over burden, ore finesand wastes deposited on hillslopes

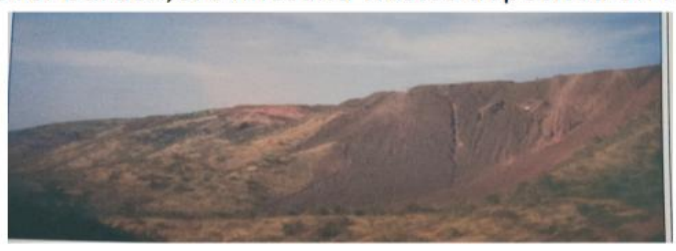

soil is fertile, silt rich due to Iron, Manganese and other nutrients derived from nearby mining areas. On account of fertility of silted land most part of these lakes or tanks are encroached for paddy and sugar cane cultivation. Therefore, abundance of ostracodes was available as they are also regarded as nitrogen fixers (Mannikeri op.cit). While the other two ponds do not contain any shells of ostracodes taxa as the bottom sediments being coarse grained /reworked sand and less vegetation. These locations where sampling was made (Garag) are situated in the western side of SSB which 
are not fed by drainage system from mining area comprising gneissic rocks which supply Sand grade sediments to the lakes. If the lakes are subjected to human activities possible of inflow of nutrients, growth of vegetation will have negative impact on the ecology of lakes studied.

The paper focuses on the use of these micro crustaceans as bio indicators and how best development of single to several assemblages are influenced by physico-chemical properties of water (salinity, temperature, $\mathrm{pH}$, dissolved oxygen, hydraulic conditions type of bottom sediment etc ( table 2). Fresh water ostracodes prefer alkaline or slightly acidic waters while some they can tolerate a wide range of $\mathrm{pH}$ from 4.6 to 13 and others are also noticed in the highly acidic waters (Fryer, 1993 \&Ruiz et al (2012)

The ostracode taxa from waterbodies of Kamalapur and Daroji lakes include Cypris subglobosa (Sowerby), Cyprinotus salinus(Brady), Hemicypris fossulata(Vavra), H.battishi Mannikeri \& Vaidya, Stenocypris major (Brady), S.hislopi(Feguson), Ilyocupris bradyi (Brady) and I.gibba are richly occurring in the Kamalapur and Daroji from water bodies and posses rich calcium content. The presence of Stenocypris major (Brady) is regarded as one of the potential bio indicator organism of metallic pollution and in toxic testing (Mohammad Shuhaimi et.al. 2011). The other crustaceans which are weakly calcified are Strandesia indica Hartmann, S.hartmanni Mannikeri \& Vaidya and Parastenocypris $\boldsymbol{s p}$ are also noticed in the former pond. It is interesting to note that some of the shells/ valves of the said species are brownish red in colour even after through washing which implies due to the richness of $\mathrm{Fe} / \mathrm{Mn}$ both in the water and soil samples of the study area. More number of Cyprinotus salinus (Brady) occurs in both the ponds and are known to be acid tolerant species. The occurrence of Cypris subglobosa and Ilyocypris species in both ponds which are known swimmers indicates that there is current activity associated with the water bodies and there by the shells are brownish in colour and movement and accumulation of $\mathrm{Fe} / \mathrm{Mn}$ dumps. However it is also presumed that the occurrence of species viz; Hemicypris, and rare occurrence of Potamocypris sp., Candona sp., Parestenocypris sp., and I.gibba also indicates that these water bodies may have thick vegetative matter as they survive in such environments (Singh, 1977). The rich occurrence of Charophytes which are brownish to brownish black in colour in the said ponds indicates the richness of $\mathrm{Fe} / \mathrm{Mn}$ in the water and they are also regarded as purifiers of water. Over all the observations indicate that there seem to be wide tolerance species under the optimum value levels pertaining to quality of the water. The ostracodes are totally absent in the other two ponds due to absence or poor vegetation and coarse grained substrate and more silicified content and less calcium carbonate.

From foregoing discussion, it is concluded/inferred that the frequency/variation of ostracodes in different in land water bodies may be due to nature of bottom sediment soft/coarse grained, rich to less calcium carbonate and vegetative matter. Higher frequency attributed to rich organic and metallic $\mathrm{Fe} / \mathrm{Mn}$ content. The study also reveals in identifying some Stressed environmental/ tolerant species which serve as the proxies of such prevailing conditions which is also noteworthy. Based on the observations made on abundance /occurrence of ostracodes on largescale in the ponds charecterised by higher concentrations of Fe,Mn , which has led eutrophication. and rarity of these species in the ponds located in gneissic terrain it is concluded that growth and occurrence of ostracodes is controlled by physico-chemical composition of waters of lakes. The observations made herein although limited however will be useful in understating the ecological/paleo- ecological applications. Similar observations have been made by Vaidya et.al (2013 Abst.) around Bengaluru lakes on impact of pollution on these micro crustaceans.

\section{REFERENCES}

[1] Anna Pint, Heike Schneider, Peter Frenzel (2016):Late Quaternary salinity variation in the Lake of Siebleben (Thuringia, Central Germany) - Methods of palaeo environmental analysis using Ostracoda and pollen https://doi.org/10.1177/0959683616670216

[2] Bhatia S.B. and Singh D (1977): Ecology and distribution of some Recent ostracodes of Vale of Kashmir, India. Micropal. V.17, No.2, pp.214-230

[3] Delrome L.D. (1969): \|Ostracode as Quaternary Paleoecological indicators .Candian Jour. Earth.Sci. Vol.6.pp1471-76

[4] Mannikieri M.S. and Vaidya A.S,. (1987): Ecology and Distribution of Recent Fresh Water ostracodes from Dharwad , Karnataka . Proc. Nat. Symp. Role of Earth Science in Environment. IIT, Bombay, pp.300-305

[5] Mathur A.K. Sushilkumar , Singh, V.P. and Vibhuti Rai(2001): Molluscs and Ostracoda as Pollution indicators in Gomti River Nat.Symp. Role of Earth. Sci. Intergrated development and related issues . Asl. Spl. Publ. No.65(11),pp.29-33

[6] Puri H.S. (1966): Ecological Distribution of Recent Ostracoda Symp. Crust. Part. Imar.Biol.Assoc. pp. 457-485

[7] Singh D. (1977): Comments on some Quaternary ostracode taxa from north west India. J. Pal. Soc. India v.20, pp366-381

[8] Faruk,Y and Okan, K (2006):Tolerance, Optium ranges and Ecological requirements of Freshwater ostracoda(Crustacea) in Lake Aladag ( Bolu, Turkey). Ecol.Res.21:165-173

[9] Mohmmad Shuhaimi-Othman, Nadzifah Yakub, NurAmalina Ramle, and Ahmad Abas (2011): Toxcity of Metals to a Freshwater Ostracode : Stenocypris major. Jour. Toxicology, pp. 1 to 7.

[10] F.Ruiz et.al (2013) : Freshwater Ostracod as environmental tracers. Int. J. Emvorpms Sci. Technol.13p.

[11] O.Kulkoyluoglu (2005); Ecological Requirements of Freshwater Ostracoda (Crustaceal) in two limnocrene springs ( Bolu, Turkey). Ann. Limnol- Int J.41(4)pp.237-246

[12] B.Padmanabha and S.L.Belgali (2008): Ostracodes of Pollution in the lakes of Mysore. J. Env.Biol., 29(3) pp. 415418

[13] Liping Zhu et al (20100 Ostracod based environmental reconstruction over the last 8400 years of Nam Co Lake on the Tibetian plateau. Hydrobiologia, 648, pp.157-174

[14] Narsimha Ramulu K. Banerjee. G.Srikanth.K. Ravindar B. And Gowri, P (2011): Seasonal Changes in the ostracod population in Relation to the Physico-Chemical Changes of A Pernnial Tank in Warangal District A.P . Int. J. Adv.Biotech and Resh. V.2. No.2 pp.286-290

[15] Vaidya et.al (2013): Distribution of Recent freshwater ostracodes from the lakes around Bengaluru" with special reference to Pollution (Abstract) Proc. XXIV ICMS, WIHG, Dehra Dun, p.167. 